\title{
Regenerated without being recreated? A soteriological analysis of the African neo-Pentecostal teaching on generational curses
}

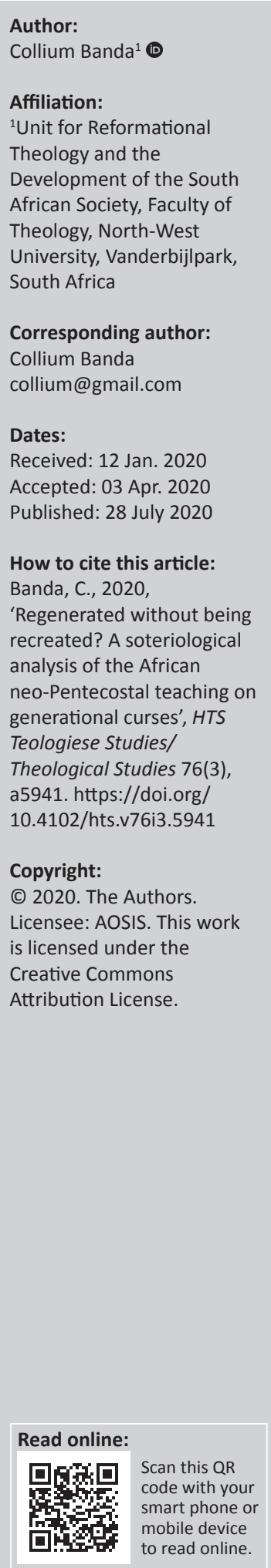

The African neo-Pentecostal (ANP) teaching that Christians continue to suffer from generational curses or bloodline curses is analysed from the perspective of Christian salvation as spiritual recreation. The main question considered in this article is: Soteriologically, how may we evaluate the ANP view that 'born again' Christians remain vulnerable to generational curses? The article describes the ANP assertion that Christians live under the threat of generational curses. Furthermore, the ANP's understanding of the nature of generational curses is examined. Attention is further given to the ANP's view of the role played by a person's blood in the transmission of generational curses and how this makes Christians vulnerable to generational curses after their conversion. The article also analyses how the doctrine of generational curses expresses a notion of Christian salvation with limited creative powers in Africa. Lastly, some elements that should inform an understanding of Christian salvation when addressing the fear of generational curses among the ANPs are proposed. The significance of this article lies in contributing a theological analysis that will help African Christians find confidence in their Christian salvation.

Contribution: The article attempts to contribute towards the formulation of a biblically informed systematic theological framework of analysing and critiquing the logic of salvation in the ANP teaching that generational curses remain on regenerated Christians.

Keywords: generational curses; African neo-Pentecostalism; salvation; spiritual security; regeneration; demons; prosperity; deliverance.

\section{Introduction and background}

This article is a soteriological critique of the African neo-Pentecostal (ANP) ${ }^{1}$ belief that 'bornagain' Christians remain vulnerable to generational curses unless they have undergone special spiritual deliverance in addition to their conversion. ANPs fall within the health and wealth prosperity movement which believes that prosperity in wealth and health is a sign of God's favour bestowed on his children. A prominent distinction of ANP is the central role played by prophetic figures who claim to be uniquely called and anointed by God. The prophets claim to be 'descendants of the line of a specially chosen few who stood before God and who shared in God's authority' (Gunda \& Machingura 2013:21). While ANPs affirm the priesthood of all believers through the democratisation of the gifts of the Spirit (Asamoah-Gyadu 2004a:391, 2004b:338), the rise or fall of each neo-Pentecostal church is determined by the perceived levels of God's anointing of the prophet. Prophets regarded as highly anointed attract large groups of followers. An important element in the operative nature of the ANPs, which is connected to the anointing of the church leaders, is 'a very strong interventionist theology' (Asamoah-Gyadu 2004b:338). This interventionist theology emphasises the immediacy of God's presence and promotes healing for the sick and deliverance for the demonically possessed or oppressed. One of the dominant focal points of ANPs is delivering people from possession and oppression by generational curses and inherited sins and freeing them to experience a life of blessed prosperity.

This article critically analyses the soteriological logic and coherence of believing that saved Christians are born again but remain vulnerable to generational curses and therefore need to constantly seek deliverance and protection from these curses. The soteriological perspective that guides this article is the aspect of regeneration that emphasises being born again into a new life in God (Jn 1:12-13, 3:3-8). Among his numerous images of the meaning of salvation, Paul categories salvation as 'the beginning of the "new creation"' (Dunn 1998:180). While this ultimately points

1.In this article ANP stands for African neo-Pentecostal or African neo-Pentecostalism according to the context. ANPs refers to African neo-Pentecostals. 
to the perfect future to be experienced at the coming of Christ, it points to the present radical new state of being entered into by the believer in Christ. Regeneration is a spiritual birth through the Holy Spirit who gives birth to the spirit (Ferguson 1996:122; Jn 3:6). Regeneration is a result of the Trinitarian work in Christian salvation, for God 'saved us through the washing of rebirth and renewal by the Holy Spirit, whom he poured out on us [...] through Jesus Christ our Saviour' (Tt 3:5). Williams (1996:50-60) highlights that soteriologically, regeneration transforms the saved person into a new creature, turns the saved person into a new spiritual being with a new nature and new life. Using this soteriological view of regeneration that impresses the idea that people who were once spiritually dead (Eph 2:1) and a target of God's wrath (Eph 2:3) have now been transformed into living beings in God (Eph 2:5), the article seeks to highlight that the ANP belief that Christians remain held by their generational curses contradicts the recreated state of saved people.

As will be elaborated below, the article works with the definition of generational curses as guilt inherited from one's ancestors. However, the article is not intended to prove or disprove the existence of generational curses, but in examining the logic of the ANP belief that Christians remain vulnerable to generational curses. The article is only interested in critiquing what it means for a Christian to claim to be saved and yet live in fear of generational curses. Therefore, establishing the reality of generational curses belongs to another article. Generally, in ANP, generational curses involve 'events from the past that affect the present in negative ways' (Asamoah-Gyadu 2004a:390). Generational or ancestral curses characterise the fruition of sinful and negative aspects in the past lives of parents, grandparents and great-grandparents. Other terms used to express generational curses include bloodline curses, ancestral curses and family line curses and affirm that these curses run down along the family lineage.

The article attempts to answer the question: Soteriologically, how may we evaluate the African neo-Pentecostal view that 'bornagain' Christians remain vulnerable to possession and oppression by generational curses? In other words, in light of the Christian salvation as rebirth into a new spiritual existence, what are the implications of the claims by ANP prophets that Christians remain held by their generational curses until they undergo a separate deliverance ritual. For example, Zimbabwean Pentecostal prophet, Emmanuel Makandiwa's (2018f) teaches that, although the Apostle Paul was born again and anointed by God, he had a demon that tormented him in his body (2 Cor 12:7). A similar statement is made by another Zimbabwean prophet, Chiza (n.d.) that:

\footnotetext{
Some of you are very powerful, mighty, you are being used by God in business and many things, but the problem is there is a demon that is pulling you back. That demon has its connection through your mother. (n.p.)
}

What is the understanding of being born again in these ANPs which makes them believe that the generational curses from their unconverted life can remain with a Christian? These neo-Pentecostals claims seem to suggest that Christian conversion is only sufficient to save people from their spiritual sins but is insufficient to liberate them from oppression and possession by African evil spirits. Therefore, we must interrogate the theological logic of the belief that converted Christians remain subject to the power of evil spirits such as generational curses.

\section{The African neo-Pentecostal assertion of the threat of generational curses to Christians}

ANPs believe that being 'born again' alone is not enough to free the believer from generational curses and even demon possession. Ghana's Archbishop Duncan-Williams' (in Degbe 2014:256), teaches that being born again does not liberate one from the dangers of curses unless the individual makes a conscious attempt to address them through the application of the blood of Christ to one's family bloodline. Therefore, to be liberated from generational curses, 'it is required of every "born again" [sic] Christian to settle something with his or her past' (Degbe 2014:256). Similarly, Makandiwa (2018a) asks an important rhetorical question:

Can I be a child of God and have a curse in my blood? Can I be born again and have a demon giving me problems? Can a Christian be possessed by an evil spirit? (n.p)

Answering his question, Makandiwa (2018a) declares:

That depends on whether you understand who a Christian is. When you got born again not all of you got born again. There is a part of you that got born again, and that part cannot be possessed by demons. But there is another part that was never born again and will never be born again. (n.p.)

This question troubles many indigenous African Christians in both Pentecostal and non-Pentecostal churches. It is common to hear counter-accusations of witchcraft, demon possession, demon oppression and even satanism among ANPs. Makandiwa expresses a dichotomous view of a person's spiritual and physical parts and suggests that only the spiritual part of a person gets born again while the human part which has the cursed blood remains untouched by Christian conversion. Makandiwa (2018a) affirmatively declares:

So you can be a liberated man, the man inside born of the Spirit
can be so powerful and yet he is limited by the physical body
that is yet to experience another dimension of the power of God
which comes at a different time depending on who is teaching
you the word of God. (n.p.)

In other words, spiritual conversion has little or no effect on the physical body of a Christian. Makandiwa further says some Christians remain unliberated from spiritual curses because some ministers do not have the capacity to deal with these curses. Justifying his position, Makandiwa (2018f) states: 
You can be a child of God, born again in the Spirit and have a demon tormenting you in your flesh. Abraham had a demon [...] called barrenness [...]. He was a friend of God, but there was a demon in his flesh. Apostle Paul had a demon (2 Cor 12:7). He was born again, he had an anointing, he would heal the sick because all that is required (to heal the sick) is to be spiritual. But in his flesh he had a demon. (n.p.)

This shows the invincible power of curses and demons to ANPs. Having a special status before God as in the case of Abraham who was God's friend and father of faith does not save anyone from demon possession and receiving blood contaminated with curses from one's ancestors. Similarly, being a chosen apostle of Christ, being filled with the Holy Spirit and performing miracles of driving out demons from other people, as in the case of Paul, does not save from demons either. Spelling out the vulnerability of the Christian, Makandiwa (2018f.) says:

This helped me to understand that being a man of God, I would still have to deal with certain physical things because I can preach fire and be physically broke. I can be a prophet and die outside prosperity not because that is the will of God but because I have failed to understand the communication of the blood. Your blood can tell you something which is totally opposite to what God is saying. (n.p.)

For Makandiwa, a born-again Christian is vulnerable to generational curses and possession by demons because only the heart or the spiritual body of the person is converted, while the physical body in which runs the cursed blood remains unaffected.

Makandiwa considers the message of 2 Corinthians 5:17 that a person in Christ is a new creature, old things have passed away and the new have come. He says the text only describes the new spiritual state of the Christian believer, but not their entire life. This is so because Christians have things they did, that continue to follow them even after their salvation. It must be noted that Makandiwa is not talking about the consequences of sins which may continue to affect a Christian despite of experiencing God's forgiveness and blessing.

Rather, he suggests that even after their conversion, curses on Christians remain and continue under the dominion of the evil powers of darkness. In other words, Christian conversion does not end the generational curses on a Christian because conversion only touches the person's relationship with God and does not affect the curses in their blood. This seems to suggest that God's salvation does not deal the person in totality but deals with the spiritual and physical sides separately. Essentially the ANP teaching on spiritual curses expresses the insufficiency of Christian salvation from spiritual forces, particularly African oriented spiritual powers.

\section{Aspects of the neo-Pentecostal belief in generational curses}

The ANP doctrine of generational curses can be complex and confusing but the following aspects can be discerned.

\section{Generational curses as the consequences of the sins of the ancestors}

A notable aspect is that generational curses are consequences of sinful actions or wrong actions committed by individuals that are negatively passed down to the succeeding descendants. This view is informed by Old Testament texts such as Exodus 20:5 that God is 'a jealous God, punishing the children for the sin of the fathers to the third and fourth generation of those who hate me.' There are various interpretations of 'third and fourth generations' among Pentecostals, but the principle is that the consequences of $\sin$ could be passed down well beyond its original perpetrators (Asamoah-Gyadu 2004b:348). Degbe (2014:255) shows Ghanaian neo-Pentecostal Archbishop Duncan-Williams using Exodus 20:5 to argue that 'until certain generational curses are dealt with, the Christian is bound to experience physical and spiritual threats and setbacks as he or she works towards freedom and material prosperity.' Thus, generational curses are inherited guilt. Biri (2018) says ANPs:

Have a need for deliverance from the ancestral past, the past lives of parents, grandparents and great-grandparents because people will be punished for sins committed by any of the preceding three generations. (p. 84)

Accordingly, people may view their suffering and lack of progress as punishment for the wrongs committed by their forbearers.

Makandiwa (2018b), defines generational curses as 'going through problems because of what your parents did.' The idea is that the present generation reaps the consequences for the wrong actions of their ancestors. Makandiwa (2018b) adds: 'You are suffering today because of a father who opened the gates of hell and certain demons came out and until today there is a great mourning and a great cry.' ANPs believe that certain actions by parents or heads of families and clans, such as the participation in traditional religious worship rituals and making negative pronouncements are a form of covenant making with evil powers (Asamoah-Gyadu 2004b:342; Meyer 1998:324). Such actions are believed to open the door for destructive demons to enter and establish their malevolent reign in the family line (Asamoah-Gyadu 2004b:342; Meyer 1998:324). To some extent this view expresses the Old Testament system of covenants, in which a covenant made by the founding father of a family spread to his posterity. As expressed by ANP prophets, the main belief is that the consequences of sins by a person's family member whether dead or alive, are recurrent in their family lines (Asamoah-Gyadu 2004b:342).

In this framework, the prevalence of negative occurrences such as chronic and hereditary diseases, emotional excesses and allergies, frequent miscarriages and deaths, suicidal tendencies, and persistent poverty within a person's family, persisting emotional difficulties and phobias, physical disabilities, 'alternative sexuality' can be attributed to generational curses (Asamoah-Gyadu 2004b:342; Meyer 1998:323-324). The idea that certain actions open doors to 
demonic elements is also alive in African traditional religions (ATR). For instance, the traditional Shona people of Zimbabwe talk of actions that provoke evil spirits, kusimudza mhepo yakaipa, and bring various types of problems on people and their investments. The understanding of generational curses as consequences of the sins of the ancestors has very strong resemblances with the ATR, where harms in people's lives are believed to have spiritual causes.

On critical reflection, it cannot be denied that in some cases children do indeed suffer the consequences of the actions of their forbearers. Some choices and actions of the ancestors have lasting positive or negative effects on subsequent generations. The Bible does present situations in which the actions of the ancestors had appropriate consequences on their descendants. However, the Bible also presents cases of righteous people, such as Job and his family, who suffered gratuitously as if to dispute the consequential view of suffering. Positively, the neo-Pentecostal view of generational curses as inherited guilt does well to impress on parents to ensure that they pass a godly and blessed heritage to their descendants. Negatively, the idea of generational curses as inherited guilt thrives on a one-sided view of God's justice that is not informed by his love, grace and mercy as a forgiving God. It lacks balance by failing to reconcile the biblical facts that the same God who swears that he does not leave the guilty unpunished and punishes the children and their children for the sin of the parents to the third and fourth generation (Ex 34:7), also says parents should not be put to death for their children, nor children put to death for their parents but each must die for their own sin (Dt 24:16). ANPs need to awaken to the complexity of this issue. Furthermore, this view can be criticised for projecting a vision of human progress that fails to account for how sin has made the world an imperfect place that awaits the return of Christ to restore the lost perfect order. The view further underplays the responsibility of individuals for their own poverty by shifting the blame to their ancestors. Not everyone is poor or suffers because of the sins of their ancestors, some people received a good inheritance or good opportunities but squandered them. It also overlooks the fact that many people in Africa are poor because of the overarching unjust or poor socio-economic and political structures that are beyond their control.

\section{Generational curses as the evil work of spirits within the family line}

ANPs also understand generational curses as 'curses caused by generational spirits which do not want members of the family to prosper' (Biri 2018:79). Sometimes ANPs blame problems such as poverty and infertility to destructive and anti-progress evil spirits within the family. According to this logic, ancestral spirits and territorial spirits are believed to 'bind' people, blocking them from prospering by causing illnesses and diseases (Biri 2018:84). It is common to hear ANPs say prayers of binding evil spirits which may hinder their activities, which is also explained as unbinding or loosening the chains of the devil. This resonates with the typical belief in African traditional religions, where misfortunes such as loss of pregnancy, an illness that hinders a person from attending a job interview or losing money on one's way to buy a car are sometimes interpreted as actions of evil spirits hindering people from prospering.

ANPs view certain antisocial practices such as witchcraft, divorce, sexual promiscuity, and self-destructive traits, habits such as laziness and a variety of diseases such as hypertension as inherited from past generations. To illustrate this type of curse, Makandiwa (2018c) says a man whose forefathers were polygamists, will struggle to be monogamous, because he would be acting against 'his inclination' since polygamy is in his genes. This presenting of generational curses as inherited bad behaviour from one's ancestors is common in ATR. It is common to hear African people blame their ancestors for lack of progress in their lives. Consequently, people born into a family with histories of dreaded practices such as witchcraft, murder, divorce or suicide, fear that these spirits will follow the family line and be inherited by some descendants and cause people to commit similar actions. In ATR, people who die certain forms of deaths such as suicide and murder do not receive normal burial rites, and some are not accorded the state of being an ancestor in order to stop their spirits from influencing future generations to commit the similar actions. This shows that some ideas among ANPs are derived from ATR. However, an even more serious weakness of this view, is that it places the responsibility for poverty and suffering on evil spirits in a way that ultimately absolves people of their own human responsibility for their suffering.

\section{Generational curses as evil spells cast on one's family}

African neo-Pentecostals also project generational curses as evil spells cast on individuals or unfavourable pronouncements spoken against individuals that have negative effects transmitted to their descendants. Makandiwa (2018a) expresses this understanding by further defining a curse as a 'statement or a negative utterance that invokes negative things in your life.' $\mathrm{He}$ adds, '[c]urses are negative declarations upon people, places, objects and even animals' (Makandiwa 2018a). ${ }^{2} \mathrm{He}$ characterises generational curses as 'plac[ing] an insult into the blood of somebody' (Makandiwa 2018e). ${ }^{3}$ Examples of such curses include statements like 'you will never prosper', which is believed to unleash poverty which spreads down one's family line. In African traditional religions, to declare a curse against a person is to bewitch them. The words of a jealous or envious person, an aggrieved person and the words spoken with the aid of evil magic are considered to have enormous power over their victims (Mbiti 1969:192). Thus, in times of misfortunes such as the collapse of a

2.Makandiwa (2018a) states: 'For one to be cursed, there is need for another to speak and the same goes for a blessing. It is very important to mind what people are saying to us in our lives.'

3.Makandiwa's use of 'insult' can be understood by the Shona word (his mother tongue), kutuka which can mean either a slur or jinx. He seems to be using 'insult' from the Shona view of jinxing someone. 
business or a marriage, it is common to hear some African people recall words by someone that their adventure will fail.

Just as the previous point, the idea of generational curses as evil spells cast on people or their families tends to apportion the responsibility for failure to spiritual powers in a way that absolves people of their own responsibility for their problems. It promotes escapism that allows people to blame their failure on other people. It is common to hear people blame witchcraft and other evil forces for their bad temper, lustful attitude or the failure to budget and failure to plan properly and follow sound principles. A challenge with this view is that failure and poverty is responded to with witch-hunting instead of critical self-analysis of one's approach to life.

\section{Generational curses as the effects of 'wrong' Christian doctrines}

ANPs such as Makandiwa also link generational curses to effects of what they call wrong doctrines and beliefs about God. These wrong doctrines include beliefs that suffering and poverty are God's will for Christians. The example is Job's statement 'the Lord gives, and Lord takes away.' Makandiwa says Bible verses such as Matthew 6:33 which says to seek the kingdom of God and his righteousness and these things will be given to you, are 'used to contaminate your blood' (Makandiwa 2018f) to accept poverty. Therefore, curses do not only come from evil statements by people, but also 'wrong' Christian teachings that poverty and suffering are God's will. Makandiwa (2018e) says,

For one to be cursed there is need for someone to release the curse, and after the curse is released there is need for the cursed to receive the curse. Unless a curse is received it cannot work in your life, if there is a curse in your life, it means that there is something you did so well - you did not curse yourself but you received the curse when it was pronounced. (n.p.)

In this excerpt Makandiwa speaks about both harmful declarations made against an individual and Christian teaching which says it is wrong to be rich. For 'curses are spoken into existence, they are not always there' (Makandiwa 2018e). Therefore, a curse is not only accepting statements from one's enemies that one will never prosper in life. To even believe that suffering is God's will, is to curse oneself. To affirm the disastrous effect of wrong doctrines on people's lack of prosperity, Makandiwa (2018f.) says:

What brought me here [undesirable situation]? Wrong information, somebody lied to me. And out of respect I obeyed him. I paid attention to wrong doctrine. A man of God preached his own mind and we believed it as a family. Now we are all broke, bound by religion. (n.p.)

In this excerpt Makandiwa is saying believing wrong doctrines effectively brings curses on the individual.

Therefore, to end the curses in one's life one must also deal with Christian doctrines that glorify suffering and poverty. Makandiwa's view of curses as wrong Christian beliefs expresses the belief in the power of positive confession which can be traced to the founders of the gospel of health and wealth such as Kenneth Haggin and Kenneth Copeland (Hellstern 1989). Positive confession has roots which can be traced to figures like Essek William Kenyon who believed in the power of one's thinking and words (Williams 2013:111113). The challenge with the view of curses as wrong beliefs and saying wrong things is that it subjects God and the spiritual realm under the control of humanity. Ultimately, whatever a person thinks and says turns into reality. This belief distorts God's goodness, justice and sovereignty, by making him subject to whatever humans desire. Furthermore, if the wrong confessions about God lead to curses, we may ask: What then about the right things that people believed about God but did not turn into positive material realities? The problem with this view is that at the end of the day, there is generally no quantification of the balance of the power of positive and negative confessions in people's lives indicating blessings received because of good confession and curses received because of wrong confessions.

In summary, ANPs primarily understand 'curses' as 'negative spiritual forces released from the spirit world by words, actions, and attitudes' (Degbe 2014:256) and are inherited from ancestors through parents or the community into which a person is born. In this perspective, generational and/or ancestral curses are cited as some of the main reasons why people suffer (Asamoah-Gyadu 2004a:390). Therefore, belief in generational or ancestral curses expresses fear of being bound and enslaved by evil spiritual powers which hinder one from attaining a prosperous and healthy life. Consequently, the central spiritual ethos in ANP is freedom from generational curses and protection from being enslaved by them.

\section{The transmission of generational curses and the vulnerability of Christians}

It is necessary to consider the ANPs' understanding of how generational curses are transmitted to people and how the curses are believed to maintain their enslaving power on 'born-again' Christians.

\section{The transmission of generational curses through people's blood}

The fear of generational curses among ANPs is based on the belief that curses reside in people's blood. This means that curses are passed through the blood that runs within the family line. As already seen above, Makandiwa (2018c) states that a man with a polygamous, ancestor receives genes of polygamy through the blood received from his ancestors. In the notion of 'bloodline curses', real blood in people's bodies functions as the channel through which curses are transmitted down the family line. Makandiwa (2018a) preaches that after conducting research he discovered that 'there are curses that manifest in our lives and show up in what we do and it is all in our blood' [author's own italics] (Makandiwa 2018a). ${ }^{4}$

4.Even though the belief in generational curses is widely held among African neoPentecostals, Makandiwa's (2018a) declaration that his knowledge on generational 
Makandiwa (2018e) bases his belief in the transmission of curses through blood on the following three biblical sources:

- the covenant God made with Abraham, when God blessed him and declared that his descendants will be blessed through him

- the statement in Leviticus 17:11 that, 'the life of a creature is in the blood'

- the statement in 2 Corinthians 3:6 in which the apostle Paul says God has made Christians ministers of a new covenant.

To Makandiwa, these biblical passages show that God does not make promises to individuals as persons but makes promises with their blood because it is the genealogical blood that transmits God's promises to one's posterity. Focussing on Abraham, Makandiwa (2018e) says God gave the blessing to Abraham's blood and not to Abraham as a person. Thus, the blood is the component in people that receives curses (and blessings) and spreads them to one's descendants. In Makandiwa's (2018e) analysis, had the blessing been given to Abraham as a person, its effects would have ended with Abraham's death but because it was given to his blood, the blessing continued to exist and be transmitted to subsequent generations.

As evidence that the curses or blessings reside in the blood, Makandiwa (2018e) points to the paradox of 'people who show a lack of commitment to God but are more materially blessed than those who show a higher commitment to God.' Using his prosperity theological perspective, he says the reason why God gives abundant blessings to godless people is because of the blessed blood from their ancestors transmitted to them (Makandiwa 2018e). It therefore follows from this perspective, that godly people can be poor because of inheriting cursed blood from their ancestors.

Makandiwa's (2018e) perspective is that a person's present situation is determined by the state of the blood - cursed or blessed - received from one's ancestors. This point shows that even born-again Christians need deliverance from curses since the blood and genes in them may carry generational curses. This perspective shows that Makandiwa, has a materialistic view of curses, but has a spiritual view of salvation. According to Makandiwa (2018e), Christian salvation cannot deal with generational curses because salvation is a spiritual reality, but curses are material realities living in the bloodstream passed from generation to generation.

Emphasising the role played by blood in the transmission of curses, Makandiwa (2018e) says 'when the blood is cursed, it ceases to operate well.' This emphasises that in generational

\footnotetext{
curses is from his own 'research and investigation' seems designed to assert his uniqueness by affirming that he is not repeating what he has heard from other people but is delivering what God has directly revealed to him. This affirms his people but is delvering what God has directly revealed to him. This affirms his prophetic authority over his people and allows him to add new extra-biblica insights into the subject. Even older nach as Kenneth Hagin projected their teachings openly derived from E.W. Kenyon, and familiar with his teachings as new in order to give the impression of having the "ability to hea directly from God and receive new revelations and insight into the "true" meanin of scripture' (Williams 2013:112).
}

curses one inherits a damaged operational system devoid of good health and material prosperity. Makandiwa (2018e) asserts that:

The economy of a country is conditioned by the blood of the people. Things are wrong around us because things are wrong in us. Before you begin to criticise or bring in the blood of Jesus, remember that you will still have to acknowledge that your own blood is dysfunctional that's why you need the blood of Jesus. (n.p.)

In plain terms, the state of the blood determines progress in our lives. Consequently, lack of progress in one's life or the manifestations of bad things such as poverty and sickness, means that one must investigate things in one's blood. He emphasises the need to understand that there are certain levels of success [that are] difficult for you to attain because someone said, "not in this generation"' (Makandiwa 2018a). That is, people are only able to achieve what the state of their blood permits them to achieve. Therefore, people who receive the blood of an ancestor who was told that he would never amount to anything, will not achieve any meaningful economic status until that curse is broken. The generational curses in the blood forbid one from breaking through in one's success.

On analysis, the ANP emphasis on the blood of ancestry keeps people dominated by their past. It promotes the idea that it is almost impossible for individuals to break off from their past and be different. This binds and enslaves Africans to their pasts in a way that discourages them from victoriously facing the future. Furthermore, it seems to express the African traditional religions (ATR) belief that a people cannot escape their origins because their ancestors will track them down and find them. Considering that past African generations are generally considered to have been primitive, the idea that their blood remains alive in modern people, inadvertently renews and perpetuates the Western idea of Africa as a dark continent and Africans as eternally benighted because the blood of their primitive ancestors remains alive in them today.

\section{The vulnerability of Christians because the blood prays to God}

How do curses function to bring about their destructive consequences on people? The answer to this question lies in Makandiwa's belief that the blood has a voice through which it prays and speaks to God in accordance with its blessed or cursed state. Blessed blood asks for blessings while cursed blood asks for poverty and suffering. Makandiwa (2018e) derives the idea that the blood has a voice from Genesis 4:10 where God told Cain that the blood of his brother Abel, whom he murdered, was crying from the ground. Basing his assertion on Genesis 4:10, Makandiwa (2018e) says, 'God seems to hear what your blood is saying more than what you say verbally.' He reasons that God did not hear Abel's verbal cry for help when he was being murdered by Cain but heard the cry of his blood because the blood speaks louder than the voice. Makandiwa (2018e) proclaims: 
As you are sleeping your blood is praying to God prayers from your blood. Imagine that you are in your bed sleeping and yet your blood is praying, have you ever asked yourself what sort of prayers are going to God from your blood as compared to what you say to him through your mouth? (n.p.)

The gist of the statement is that the blood has a voice that is more audible to God than a prayer uttered verbally. The implication of Makandiwa's assertion is that through our blood we subconsciously say prayers to God which are more effective than those we consciously utter with our mouths. Makandiwa says the prayers that proceed from our blood are more effective in compelling God to act, than prayers verbally pronounced. This means that we must diligently pay attention to the state of our blood and what it says to God. Makandiwa impresses that generational curses must be taken seriously because they condition or programme how and what a person's blood prays to God. Makandiwa (2018e) claims:

If your blood can speak, it will only speak from the information given to it by someone because your blood is like a computer there is nothing a computer can give you unless what was given to it. The language of your blood was structured by somebody. The language of your blood, what your blood is saying, was given to it by someone. Someone said something and you believed it, or maybe your father believed it. It is very possible to believe a lie. (n.p.)

The information in the blood refers to the curses in the blood. The statement highlights the power of curses spoken against a person which then contaminate the blood in a person's life resulting in one's state of cursedness. The curses can determine what he or she requests from God, good things or bad things. As he further puts it: 'You are carrying something in your system that has a language which you should understand' (Makandiwa 2018a). Therefore, the curses and the sins of the past generations remain alive today even if the people who were directly affected by those curses and sins are long dead. The full implications of the idea that the blood speaks is that 'if the life of the flesh is in the blood, then it means the blood designs for you the lifestyle that you want or don't want' (Makandiwa 2018a). Therefore, all efforts must be taken to cleanse curses from one's blood. What needs to be cleansed from a person's blood also includes Christian doctrines that ANPs classify as false doctrines such as that suffering is God's will. The foundational belief among ANPs such as Makandiwa and Duncan-Williams is that 'life in its totality is not an event, but a historical continuity' (Degbe 2014:255). The curses incurred by one's forbearers continue to exist throughout the existence of the line of descendancy.

\section{Inconsistencies in the belief that generational curses are transmitted by blood}

Several critical observations can be made against Makandiwa's notion that curses reside in people's blood. If generational curses and blessings reside in the blood, and if indeed God's covenant with Abraham was made with his blood, how is it that the blessing in his blood seems to have only followed Isaac and did not pass on to his other children like Ishmael, his firstborn child and son by Haggar (Gn 16:1-4)? The blessing in Abraham's blood does not seem to have followed his other children born by Keturah (Gn 25:1, 6). Furthermore, if it is true that generational curses are genetically transmitted through one's bloodline from one generation to the next, how do we explain that from Abraham's twin grandsons, Esau and Jacob, the Abrahamic blessing seems to only have followed Jacob? What do we say about the blood of Abraham in Jacob's twin brother Esau, who seems to lack Abraham's blessings and whose descendants eventually disappear from the biblical narrative of the Abrahamic covenant and blessing?

Furthermore, Makandiwa's idea that people speak to God through their blood and that the prayer of the blood is more audible to God than the prayer of the mouth has no biblical basis. It further contradicts explicit extensive biblical emphasis for carefully and consciously verbalised prayer to God through faith (Mt 6:5-8; Ja 5:16). Another serious problem about the idea that God listens more to the prayer of the blood than to a person's consciously uttered prayer is the impersonation of God and treating him as an impersonal power. The Bible presents God as a personal divine being, who is sovereign and good, loving and answers his people's prayers by personally relating to them, not through some impersonal process that uses words that are magically uttered.

Furthermore, as has already been noted in earlier sections, Makandiwa's theology of generational curses, according to his various works examined so far, reflects some strong nuances of ATR. Many indigenous southern Africans have a concept of ill luck, called umnyama in the Nguni languages, thought to reside in a person's blood or body that overshadows them causing all kinds of failures and misfortunes. In some ATRs, a person who always misses good opportunities may be figuratively described as one with bad blood that chases away or repels good things but invites harm and all kinds of bad things. For instance, the Zimbabwean Ndebele people believe that there is a correlation between bad blood (igazi elibi) and ill luck (umnyama or isinyama). The same concept also exists among the Shona people, leading to the belief that the power of curses, hereditary diseases and inherited disabilities is activated in bad blood' (Dodzo, Mhloyi \& Dodzo 2018:133). It is a serious stigma in many African traditional communities when one is classified as a person with bad blood, umuntu olomnyama. Such a person is often blamed for the misfortunes in the family or group. Consequently, many traditional Africans invest heavily to ensure that their blood is clean, endowed with luck, inhlanhla, and is free from any bad elements that may attract misfortune. Therefore, the idea that Christian conversion is insufficient to completely eradicate generational curses and their effects on people is a serious disappointment to many African Christians. It also creates serious vulnerability leaving believers either holding on to their ATR practices or totally depend on the ANP prophets to find relief from their generational curses. 


\section{The belief in generational curses as an expression of Christian salvation with limited creative powers in Africa}

The ANP belief in generational curses as discussed so far, particularly the emphasis that born-again Christians remain vulnerable to curses, indicates a poor understanding of Christian salvation.

\section{A limited view of the extent of salvation}

The ANP's consuming belief in generational curses reflects an understanding of the term 'born again' that lacks sufficient understanding about the extent of being born again. ANPs do emphasise being born again as 'complete break with the past', (Meyer 1998), and unlike many traditional missionary churches, they view Christian conversion in radical terms of discontinuity of the former life and a fresh beginning of a new life in Christ. But their belief that one can be a born-again Christian and yet remain subject to generational curses until they have undergone special deliverance by anointed man of God, contradicts what is meant by being born again (Jn 3:3).

Makandiwa's (2018e, 2018f.) proclamation that being born again does not completely liberate Christians from generational curses because the curses reside in the person's blood, expresses a limited salvation unable to deal with the whole soteriological needs of a person. The idea that Christians can be born again and yet retain spiritual curses in their blood is not well informed by the process of conversion as outlined in the Bible. The biblical process of conversion which encompasses repenting from sin, turning to God, renouncing all lords and submitting to Christ by confessing him as Lord and Saviour and dying with Christ and be resurrected with him in the rite of baptism, shows being recreated anew. Ultimately, the teaching about generational curses projects the idea that Christian conversion has limited creative powers in Africa, which must be complemented by efforts of anointed prophets (Banda 2018; Magezi \& Banda 2017).

\section{The promotion of living a Christian life dominated by one's preconversion life}

ANPs show a limited creative power of being born again by constantly referring to the fearful power of abandoned ATR spirits when one embraces Christ. Birgit Meyer's (1998) analysis of ANPs in Ghana made some two decades ago, remains true today. Meyer (1998) found that while traditional mission Christianity:

[M]aintains that conversion implies crossing over the boundary between 'heathendom' and Christianity once and for all, and there is [therefore] no need for Christians to look back and talk about demons, pentecostalists churches continuously dwell on this boundary. (pp. 321-322, [author's own italics])

They dwell on the boundary by being continuously controlled by the preconversion condition and finding it 'important to keep on fighting Satan, who is believed to be operating in the guise of traditional spirits [such as generational curses]' (Meyer 1998:322). ${ }^{5}$ Instead of being preoccupied with the liberated realm in Christ, ANP religion is often driven by fear of abandoned ATR spiritual powers. Meyer (1998) quotes a tormented African Pentecostal woman stating:

You see, spirits don't die, thus when you invite one into your family he comes and stays. Only you [as an individual] can try to get out of it, but still he will be in there. He will be there until Jesus Christ comes. (p. 333)

This fear of evil spirits creates a religiosity preoccupied with fighting abandoned spirits instead of serving God. It is backward oriented instead of future (eschatological) oriented. The dwelling on the past resembles the ATR view of salvation as deepening one's grip on the 'vital force' and drawing from it power needed for one a flourishing existence. ${ }^{6}$ Despite claiming to be born again, as many neo-Pentecostals continuously undergo deliverance sessions, indicates a constant loss of grip on the vital forces resulting in one being overpowered by the evil forces.

\section{The undermining of Christian salvation by exaggerating the power of evil spirits}

Sometimes ANPs exaggerate the power of evil spirits and by so doing undermine the liberating power of Christian salvation. For example, Makandiwa preached a sermon entitled 'Pre-Adamic generation' (2018c, 2018d). In it he stated that demons are spirits of people created before Adam that rebelled against God and were punished by destruction with an earlier than Noah's flood (Makandiwa 2018d). According to Makandiwa (2018d) the pre-Adamic flood could only destroy the physical bodies of the rebellious people but not their spiritual bodies 'because spirits cannot be killed by water.' Makandiwa (2018d) further says that Noah's flood also failed to kill the spirits of the rebellious people, but only killed their physical bodies. The idea that the flood waters could not kill the spirits of the people who rebelled against God implies that conversion did end the hold or power of demons over Christians. There is a difference between acknowledging the reality of the power of evil and admiring the indestructibility of demons in a way that instils great fear among Christians. This view of demons, that has no biblical basis, treats demons as being so invincible and elusive that even God failed to deal with them decisively. Any ordinary Christian who hears that demons eluded God's attempts to kill them is left in great trepidation about Satan and the demons.

ANPs focus on the African preconversion state and magnify the power of evil because of uncritically incorporating and endorsing the ATR world view. They should instead construct a new world view informed by God's sovereignty (2 Chor 20:6), Christ's victory on the Cross (Heb 2:14) and his 5.On large scale, the ANP tendency to focus on the past reflects lack of grounding on the hope of Christ's second coming.

6.For a detailed definition and discussion on the notion of vital force in ATR, see Magesa (1997:45, 50), Turaki (1999:182-187). 
enthronement at the Father's right hand (Heb 1:3). For instance, the belief that being born again does not completely end generational curses because they reside in the blood, is not biblical but is similar to the Shona belief that an inherited spirit to practice witchcraft cannot be completely exorcised from a person, uroyi hwedzinza hauperi (Biri 2012:3). Furthermore, the idea that a Christian must consciously untie bonds, bondages and covenants with the satanic by verbally renouncing any known or unknown links with the past, expresses the ATR view of salvation as gaining access to an impersonal mystical power. This leads to a notion of salvation by incantations instead of salvation as having a personal relational faith with God. Here the idea is that one is saved because of the words one uttered instead of turning to God in personal faith and having a personal relationship with him.

\section{Some soteriological points in addressing the Christian fear of generational curses}

Because the ANP teaching about generational curses is based on the continuation of a person's preconversion spiritual condition, (usually ATR oriented) into their converted life, this teaching must be challenged by emphasising the recreative nature of salvation. The idea that born-again Christians continue to suffer from generational curses incurred in their past spiritual life, is in conflict with the biblical view of salvation as spiritual recreation that transforms the person's ontology.

\section{Salvation as spiritual recreation resulting in a blessed state of being}

Christian salvation is an act of spiritual recreation transforming people from a cursed state to a blessed one. Paul states: 'If anyone is in Christ, he is a new creation; the old has passed away, behold, the new has come' (2 Cor 5:17). In Galatians 6:15 Christians are described as a 'new creation'. This points to salvation as a recreative event that transforms the believer's cursed and corrupted state of being ( $R m$ 3:23) into a new and blessed one. At conversion Christians do not just receive a new status, they are destroyed and recreated anew.

The recreated nature of the Christian is elaborately described in Romans 6:1-11 where baptism is depicted as death and resurrection into a new life. ${ }^{7}$ Dunn (1998:324) highlights Paul's understanding of salvation as a new beginning with a definite starting point in which a 'transition was involved, an ending and a beginning, a step across a chasm, a jump to [a] new plane, the experience of new life.' To affirm his view that salvation has a decisive point of beginning, Paul uses the images of death,

7.Kruse $(2012: 260)$ explains that baptism functions in Pauline literature "as an initiatory rite underpon by their their Lord. It is a part of the full conversion-initiation experience that involves repentance and faith in Christ expressed in submission to baptism on the part of the convert, when God for his part grants forgiveness and the gift of his Spirit. crucifixion, burial, Resurrection with Christ to indicate that conversion alters the person's spiritual ontology. Although Romans 6 is mainly concerned with exhorting Christians towards holiness by calling them to abandon a life of sin and dedicate themselves to God as instruments of righteousness, its emphasis on the radical new state of the born-again Christian has much to offer in addressing the fear of generational curses. It points to the fact that Christian conversion is a form of destruction of the old person condemned by sin and the reconstruction of a new person in a blessed new state.

This new state does not only affect the moral conduct of Christians, but their entire life, including the issues of generational curses. Paul's emphasis that:

[O]ur old self was crucified with him so that the body of sin might be done away with, that we should no longer be slaves to sin-because anyone who has died has been freed from sin. (Rm 6:6-7)

ultimately points to liberation from Satan's reign to Christ's blessed reign (Col 1:13-14). It therefore does not make soteriological sense for born-again Christians to view themselves as bound by generational curses.

\section{Salvation as the exclusive work of God}

The ANP teaching on generational curses must be challenged by the biblical fact that salvation is the exclusive work of God, and not of the prophets (Eph 2:8-9). The fearful belief that Christians are vulnerable to generational curses thrives on a soteriology that is not well grounded on the fact that spiritual regeneration is an act of God. The recognition that salvation is the exclusive work of God will help Christians to realise that God does not give birth to Christians (Jn 1:13; Ja $1: 18 ; 1 \mathrm{Pt} 1: 23)$, only to leave them wallowing in their inherited curses. Erickson (1998:955) explains that regeneration is completely God's doing as he transforms individual believers by 'giving them a new spiritual vitality and direction to their lives when they accept Christ.' The ANP belief in generational curses leads us to ask the question: Does God give his people salvation that leaves them without liberation from oppressive evil spiritual powers?

Saving people from oppressive evil powers is an urgent priority of God's, he was willing to pay the ultimate price to save his people (Jn 3:16). Magezi and Magezi (2016:6) amplify J.I. Parker's conclusion that 'the Bible itself highlights salvation as its central theme.' The promotion of generational curses by ANPs must be confronted with the soteriological fact that:

$[I] \mathrm{n}$ the incarnation, death, resurrection and ascension, God in Christ saved humanity from the pandemic of death and corruption, which they find themselves in as the result of Adam's sin. (Magezi \& Magezi 2016:6)

The aspects of incarnation, death, Resurrection and ascension of Christ have several implications such as redemption, atonement, forgiveness of sins and reconciliation with God. 
All these aspects pose serious challenges to the belief in generational curses:

[F]or if God has rescued us from the dominion of darkness and brought us into the kingdom of the Son he loves, in whom we have redemption, the forgiveness of sins. (Col 1:13-14)

it does not make any biblical sense for Christians to believe that the inherited sins of their ancestors continue to reign over them.

The recognition of salvation as the work of God is an important step in critiquing the doctrine of generational curses, for ANP prophets often subject believers to extrasalvific processes as if salvation is their own work. Recognition that salvation is God's work will prevent situations such as one noted by Biri (2012:5) of a pastor who threatened a spiritually troubled girl that he would leave her like that because she was 'failing to maintain your deliverance.'

\section{The comprehensiveness of the recreative work of Christian salvation}

The recreative work of the Christian salvation has a comprehensive effect on new believers. This comprehensive effect challenges the already noted teaching by ANPs such as Makandiwa (2018a), that not all of the person becomes born again. The comprehensive recreative effect of salvation means that Christians are saved as whole human beings and not partially. Paul's already noted statement that a Christian is a new creature (2 Cor $5: 17$ ) shows that salvation has a comprehensive effect, affecting all aspects of the Christian's entire life.

Grudem (1994:701) states: 'Scripture views regeneration as something that affects us as whole persons.' The scriptural affirmation that our 'spirits are alive' to God after regeneration ( $R m$ 8:10), apply to our entire being because regeneration affects us as whole persons (Grudem 1994:701). Makandiwa's position that salvation does not affect generational curses because they reside in the person's blood, and that salvation only affects a person's spiritual component cannot be soteriologically true. For, ' $[i] \mathrm{t}$ is not just that our spirits were dead before - we were dead to God in trespass and sins (Eph 2:1)' (Grudem 1994:701). In other words, since we were dead to God in our entire being, we were saved in our entire being. Christian conversion is a comprehensive reality that affects every part of our individual being. Therefore, there is no biblical and theological basis for Makandiwa's truncated soteriology that salvation is a spiritual act unable to deal with generational curses because the curses reside in our blood. Biblical texts such Romans 12:1-2 that call Christians to renew their minds, must not just be interpreted morally, but comprehensively because they speak to the Christian's entire being.

The comprehensive effects of Christian salvation are immediate because at the point of salvation God grants his people complete salvation, not half portions. As already noted, ANP teach that deliverance from spiritual curses is progressive and not instant, hence the need for extra-salvific rituals from the 'Anointed man of God' to complete one's salvation. However, Scripture shows that Christians receive complete salvation immediately at their point of conversion, although the full extent of its completion will be consummated at Christ's second coming, when the power of sin is finally destroyed. Erickson (1998:957) rightly argues that Scripture presents salvation as 'instantaneous' by speaking of believers as 'born again' or 'having been born again' rather than as 'being born again'. Although Scripture presents salvation as a past occurrence - 'we were saved', present - 'we are being saved' and future - 'we shall be saved', it never presents the salvation Christians experience in this life as partial. For instance, Paul refers to Christian salvation as a 'rescue [...] from the present evil age' (Gl 1:4) to indicate that Christians have received complete salvation. The Bible uses various metaphors to describe the completeness of the salvation given to the Christian in the 'now' such as being justified (Rm 8:1), being blessed by God (Eph 1:3), being made alive with Christ (Eph 2:5), being reconciled to God (Col 1:22) and being citizens of heaven (Phlp 3:20).

What is progressive is the maturation process of growing in Christlikeness (Erickson 1998:957), under the work of the indwelling Holy Spirit and through discipleship by mature Christians, but not as an extra-salvific work by prophets. The comprehensiveness of Christian salvation is affirmed by the fact that the ultimate goal of Christian salvation is reversing the comprehensive effects of the sin of Adam on humanity. As Erickson (1998) rightly points out:

$[T]$ he new birth is the restoration of human nature to what it originally was intended to be and what it in fact was before sin entered the human race at the time of the fall. (p. 957)

Moreover, this comprehensiveness of Christian salvation must include a meaningful response to the problem of evil and suffering. At the heart of the ANP teaching on generational curses is to make sense of inexplicable pain and suffering, with pain and suffering viewed as a curse to be rejected at all cost. Makandiwa is highlighted in the above sections calling Abraham's barrenness, Job's sufferings and Paul's thorn in the flesh as demons. This shows that ANP has a simplistic theology of pain and suffering which treats them as something to be rejected. Consequently, the comprehensiveness of Christian salvation must provide meaningful answers to the problem of perpetual pain and suffering in Africa. This means that Christian salvation must unpack what it means to be saved and blessed by God and yet struggle with problems such as infertility, sickness, poverty and economic injustice, to name but a few.

\section{The sacrificial death of Christ in the liberation from generational curses}

The sacrificial death of Christ has brought spiritual freedom and makes it a serious scandal to teach that born-again 
Christians can continue to wallow in generational curses unless they undergo spiritual deliverance by ANP prophets. Christ died as a sacrificial lamb to atone for all humanity's sins and reverse the full effects of Adam's curse ( $R \mathrm{~m} 5: 17)$. To be a Christian is to be fully redeemed by Christ from the complete effect of Adam's curse, even though the full effect of redemption awaits Christ's second coming. Therefore, to teach that Christians remain victims of generational curses is to say there are certain sins that the sacrificial death of Christ is insufficient to address. The sacrificial death of Christ means that no person should ever have to sacrifice anything for their salvation or give expensive gifts to pastors and prophets as a way of finding deliverance from generational curses. The sufficiency of the atoning death of Christ challenges all requirements of extra-salvific rituals in order to be liberated from generational curses.

\section{Conclusion}

The fear of generational curses among ANPs is real. The quest for liberation from generational curses is one of the driving forces behind the ANP movement. Many ANP pastors and prophets have established entire ministries specialising in delivering people from generational curses. Neo-Pentecostalism has spread its tentacles across many Christian traditions, as many African Christians from traditional conservative churches have embraced some of its aspects. Therefore, there are strong indications that many African Christians struggle with the fear of generational curses. Furthermore, aspects of generational curses also exist in ATR meaning this is a sub-conscious fear among many Africans. A study purely focusing on the fear of generational curses among conservative Christians in non-Pentecostal churches may yield interesting results.

The main question dealt with in this article was: Soteriologically, how may we evaluate the ANP view that 'born-again' Christians remain vulnerable to generational curses? The article highlighted that the ANP teaching on generational curses projects a problematic notion of Christian regeneration without spiritual recreation or renewal. The ANP teaching that Christians remain bound by generational curses unless they undergo extra rituals of deliverance by prophets is not sufficiently informed by the full reality of the conversion process. The idea that born-again Christians remain with generational curses is challenged by the fact that to be born again is to be recreated anew. For, according to Romans 6:3-4, 'at the time of our conversion-initiation/baptism [...] God's decision in our favour becomes effective, we receive a new status [...] we are actually renewed by the Holy Spirit' (Kruse 2012:263). Therefore, ANPs should replace their constant reference to people's cursed past with a reference to the new recreated state that will be consummated at the awaited coming glorious eschaton (1 Th 4:16-18). The significance of this article lies in contributing a theological analysis that will help African Christians find confidence in their Christian salvation.

\section{Acknowledgements}

Dr Tendesayi Kufa-Chakezha read the final draft manuscript and offered helpful comments.

\section{Competing interests}

The author declares that he has no financial or personal relationships which may have inappropriately influenced him in writing this article.

\section{Author's contributions}

I declare that I am the sole author of this research article

\section{Ethical consideration}

This article followed all ethical standards for a research without direct contact with human or animal subjects.

\section{Funding information}

This research received no specific grant from any funding agency in the public, commercial or not for profit sectors.

\section{Data availability statement}

Data sharing is not applicable to this article as no new data were created or analysed in this study.

\section{Disclaimer}

The views and option expressed in this article are those of the authors and do not necessarily reflect the official policy or position of any affiliated agency of the authors.

\section{References}

Asamoah-Gyadu, J.K., 2004a, 'Mission to "set the captives free": Healing, deliverance, and generational curses in Ghanaian Pentecostalism', International Review of Mission 93(370/371), 389-406. https://doi.org/10.1111/j.1758-6631.2004.tb00468.x

Asamoah-Gyadu, J.K., 2004b, 'Of "sour grapes" and "children's teeth": Inherited guilt, human rights and processes of restoration in Ghanaian Pentecostalism', Exchange 33(4), 334-353. https://doi.org/10.1163/1572543042948295

Banda, C., 2018, 'Complementing Christ? A Soteriological evaluation of the anointed objects of the African Pentecostal prophets', Conspectus, Special Edition, December, 55-69.

Biri, K., 2012, The silent echoing voice: Aspects of Zimbabwean Pentecostalism and the quest for power, healing and miracles, viewed 03 April 2014, from http://uir.unisa. ac.za/handle/10500/6609.

Biri, K., 2018, 'Health and wealth in Zimbabwean Pentecostalism: The case of the Zimbabwe Assemblies of God Africa (ZAOGA)', in L. Togarasei (ed.), Aspects of Pentecostal Christianity in Zimbabwe, pp. 73-89, Springer, Cham, Switzerland.

Chiza, B., n.d., Deliverance from your mother's womb. Recorded audio sermon, Eagle Life Assembly Church, Bulawayo.

Degbe, S.K., 2014, “'Generational Curses” and the "Four Horns"', Journal of Pentecostal Theology 23(2), 246-265. https://doi.org/10.1163/17455251-02301007

Dodzo, K.M., Mhloyi, M. \& Dodzo, M., 2018, 'Blood drain: A threat to maternal health in Zimbabwe', American Journal of Health Research 6(6), 130-137.

Dunn, J.D.G., 1998, The theology of Paul the apostle, W.B. Eerdmans, Grand Rapids, MI.

Ferguson, S.B., 1996, The Holy Spirit, InterVarsity Press, Downers Grove, IL.

Erickson, M.J., 1998, Christian theology, 2nd edn., Baker, Grand Rapids, MI.

Grudem, W.A., 1994, Systematic theology: An introduction to biblical doctrine, IVP, Inter Varsity Press, Leicester.

Gunda, M.R. \& Machingura, F., 2013, "The "Man of God": Understanding biblical influence on contemporary mega-church prophets in Zimbabwe", in E. Chitando, M.R. Gunda \& J. Kügler (eds.), Prophets, profits and the Bible in Zimbabwe: Festschrift for Aynos Masotcha Moyo, pp. 15-28, University of Bamberg, Bamberg. 
Hellstern, M., 1989, 'The "Me Gospel": An examination of the historical roots of the prosperity emphasis within current charismatic theology', Fides et Historia 21 78-90.

Kruse, C.G., 2012, Paul's Letter to the Romans, Wm. B. Eerdmans, Grand Rapids, MI.

Magesa, L., 1997, African religion: The moral traditions of abundant life, Orbis, Maryknoll, New York, NY.

Magezi, V. \& Banda, C., 2017, 'Competing with Christ? A critical Christological analysis of the reliance on Pentecostal prophets in Zimbabwe', In die Skriflig 51(2), a2273. https://doi.org/10.4102/ids.v51i2.2273

Magezi, V. \& Magezi, C., 2016, 'Soteriology on the interface of traditional African religion and Christianity: Engaging Bediako's soteriology and a soteriologica alternative', In die Skriflig 50(1), a2068. https://doi.org/10.4102/ids.v50i1.2068

Makandiwa, E., 2018a, Bloodline curses: The voice of the blood, viewed 04 May 2019, from www.ufiministries.org/sermon/bloodline-curses.

Makandiwa, E., 2018b, Exemption from the father's curse: Bloodline curses, DVD, UFI Ministries, Harare.
Makandiwa, E 2018c, Pre-Adamic generation: DVD Disc B, UFI Ministries, Harare. Makandiwa, E 2018d, Pre-Adamic generation: DVD Disc A, UFI Ministries, Harare.

Makandiwa, E 2018e, The voice of the blood: Bloodline curses, DVD Disc A, UFI Ministries, Harare.

Makandiwa, E 2018f, The voice of the blood: Bloodline curses, DVD Disc B, UF Ministries, Harare.

Mbiti, J.S., 1969, African religions \& philosophy, Heinemann, London.

Meyer, B, 1998, “"Make a complete break with the past": Memory and post-colonial modernity in Ghanaian pentecostalist discourse', Journal of Religion in Africa 28(3), 316-349. https://doi.org/10.1163/157006698X00044

Turaki, Y., 1999, Christianity and African gods: A method of theology, IRS/PU for CHE, Potchefstroom.

Williams, J.R., 1996, Renewal theology: Systematic theology from a charismatic perspective, Zondervan, Grand Rapids, Ml.

Williams, J.W., 2013, Spirit cure: A history of Pentecostal healing, Oxford University Press, New York, NY 